\title{
Model of Internal Marketing in Enhancing Tourism Brand of North Sulawesi, Indonesia
}

\author{
N H J Mandey ${ }^{1}$, D I Sundah ${ }^{2}$, Mikke Marentek ${ }^{3}$, Cysca Langi ${ }^{4}$ \\ \{nhjmandey@gmail.com ${ }^{1}$,dvogessundah@yahoo.com ${ }^{2}$, marentek_mikke@yahoo.com ${ }^{3}$ \} \\ Politeknik Negeri Manado, Indonesia ${ }^{1,2,3,4}$
}

\begin{abstract}
The restaurant industry in Indonesia has experienced very rapid growth in recent years. Restaurants are increasingly aware of the need to market, develop and promote the restaurant industry as part of tourism products. Currently, in North Sulawesi, the internal marketing brand has not been well developed. The results of the 2016 study showed that training and development in restaurants were still low. Also, employees who work in restaurants only pay attention to their task areas and are not customer oriented. This has an impact on internal marketing brands that have not been maximized. Therefore, this study aims to analyze the meaning of "internal marketing" according to managers/owners and employees and to analyze the meaning of the relationship "internal marketing" with "brand" restaurants in North Sulawesi according to managers/owners and employees. Quantitative research methods will be used with PLS analysis tools to analyze data. The perception of 181 respondents from the questionnaire obtained the results of the study of the meaning of "internal marketing" according to employees that employees are needed in channeling brand value and employees are internal customers who direct internal brands.
\end{abstract}

Keywords: internal marketing, internal branding, tourism

\section{Introduction}

The growth of the restaurant industry in Indonesia is quite rapid; this can be seen in the data released by the Central Bureau of Statistics since 2010-2015, income from the restaurant sector has increased, namely: 3.21 billion to 4.66 billion. The number of seats per year on average 131 seats compared to guests who came 227 people per year. This data showed that there are still quite large inequalities seen. The results of the study found that restaurants have a significant role in determining tourist destinations on vacation. Before or after being in a tourist place, the restaurant became the focus of tourist attention. The same thing states that consumers are increasingly increasing their attention to cuisine and visiting destinations for culinary tourism trips. Mass media, tourists and the tourism industry are increasingly aware of the need to market, develop and promote the restaurant industry as part of tourism products [1] [2] [3]. The attention of consumers who are growing in the food sector has motivated restaurants and the tourism industry (tourism) to unite their strengths and be present in meeting the culinary needs of tourists (tourists). However, the Head of the North Sulawesi Province Tourism Office (2016) stated that departmentalization was the main problem for the tourism industry in North Sulawesi because employees only worked for their task areas and were not customer oriented. Meanwhile, the results of previous studies 
explained that internal marketing facilitates corporate brands and employees to be an important factor in building a company's brand.

The results of previous studies showed that internal marketing was built by four dimensions, namely: internal communication, reward strategies, training and development and senior leadership [4]. The similar thing was found by Papasolomou and Vrontis [5] stated that the four elements that make up internal marketing were: (1) seeing employees as internal customers; (2) Service standards to meet customer expectations; (3) training and employee behavior formation programs; (4) Prizes.

\section{Internal marketing}

Internal marketing has developed very rapidly, but there has been little systematic research on how internal marketing works in practice [6] [7] [8].

There are five internal marketing orientation dimensions, namely: informal information generation, formal face to face information generation, formally written information generation, information dissemination and responsiveness [9]. On the other hand, there are also those who state that the five dimensions are management support, human resources management, external education, internal communication and educational training [10]. he benefits of internal marketing come from four primary sources, namely: low employee turnover, improved service quality, increased employee satisfaction and improved ability to implement changes within the organization [11].

Internal marketing item [6]:

1. Reward Strategy. Most companies ventured to build the goals and objectives of individuals and companies through reward strategies to maintain trust. Rewards can be tangible and intangible. Their employees as part of the organization's owners will prefer to work towards retaining the corporation as they hope to get more advantages.

2. Internal Communication. Internal standards are an important element of the internal marketing program. Organizations provide great services to compile high standardized performance. The standard aims to improve employee and customer relations. Standard examples of services by banks regarding service quality such as: responding to questions and customer complements without delay, answering the telephone in 3 rings, friendly and polite between internal and external customers.

3. Training and Development. The internal marketing that is practiced in companies aims to create a service-oriented work climate and motivate companies to deliver high-quality services. This means that the organization is building a strong corporate brand. Programs that have been labeled as customer care aimed to establish the work ethic of employees.

4. Senior Leadership. Managers and employees shared the view that internal marketing creates an employee mentality that encourages individuals to focus on delivering high quality for their internal services. The success of internal marketing practices has the potential to develop and demonstrate a strong relationship and build a strong corporate brand. Other research findings [5] beside to train and motivate frontline service providers to external customers but also how to serve internal marketing. Internal marketing practices emphasized the importance to interact among the employee.

This study will use the dimensions of internal marketing variables derived from research results [6]. 


\section{Brand}

Brand identifies the source or product makers and allows consumers to demand responsibility for their performance with certain manufacturers or distributors. The brand also carried out functions: simplifying handling or tracking products, helping to organize inventory records and accounting, offering legal protection, can be protected through trade names, patents, copyrights and property rights.

Branding is to give brand strength to products or services, and the goal is to create differences between products. This difference is often associated with the attributes or benefits of the product itself. Brand equity is an added value given to a product or service. Criteria for choice of brand elements: memorable, meaningful, liked, can be transferred, can be adjusted, can be protected.

A brand is a single idea/concept that is owned by a product in a prospect's mind. A successful seller must be around his generic product with some satisfaction values. Brands vary in number, strength, and value that are within the market place. Some brands are unknown to many buyers, while others have a high degree of brand awareness. Some brands have a high degree of loyalty. A powerful brand has a high brand value. Brand equity is only a reflection of market share. Brands have high brand equity that broadly has higher loyalty, name awareness, perceived quality, strong brand associations and other assets such as trademarks and channel relationships [12]. A brand with robust reasonableness provides many competitive advantages for the company. A strong brand pleases consumers who are aware of brands at a high level, quality, performance, reputation and brand name bring a high level of trust, so the company easily launches and expands the brand. A powerful brand offers the company a defense against high competition.

\section{Brand commitment}

Internal branding is aiming to form a shared understanding of brands across all company employees. Other studies [13] found a positive influence on the relationship between internal branding instruments and the delivery of their brand promises, namely brand identification, brand commitment, and brand loyalty. In the end, these attitudes also influence the way in which employees provide services.

If employees feel the relationship with the company becomes positive and worthy of being maintained, then employees have a high commitment to the organization. Commitment is therefore considered a key variable in determining the success of the organization [14]. Employees' feelings influence their choice of work. Commitment produces employees who are willing to make extra efforts on behalf of the company, so the performance of employees in their work environment is a significant reason for organizational commitment. Therefore employees, who are satisfied with their work environment tend to or have the desire to do good for customers. Such behavior, which is identified as employee behavior that is "above and beyond the norm", but is colored by the brand values of the organization, giving rise to positive organizational results. Brand commitment is a psychological attachment or feeling of having an employee towards an organization.

\section{Internal brand}

Internal branding has helped the organization to promote the brand inside, that is to employees [6] with the aim of ensuring compliance between internal and external brand messages. That is, the message of the brand (i.e. the promise of the brand) is changed by the employee into a reality that 
reflects the customer expected experience. Creation of internal branding is through internal marketing (IM) practices. Internal marketing is a means to create internal commitment among employees by adopting the concept of marketing internally.

Table 1. Summary of research results about internal marketing and brand

\begin{tabular}{|c|c|c|}
\hline Researchers & focus the research and methods & results \\
\hline $\begin{array}{c}\text { Racolta-Paina } \\
\text { and Mone (-) }\end{array}$ & $\begin{array}{c}\text { How internal marketing can add } \\
\text { valued during an economic } \\
\text { recession. Observations on IT in } \\
\text { Romania }\end{array}$ & $\begin{array}{c}\text { Internal marketing } \\
\text { facilitates the } \\
\text { development of } \\
\text { company brands }\end{array}$ \\
\hline $\begin{array}{c}\text { Ye Chen and } \\
\text { Jing Zhao } \\
(2010)\end{array}$ & $\begin{array}{c}\text { Analized the important role of } \\
\text { employees in the process of } \\
\text { service branding. }\end{array}$ & $\begin{array}{c}\text { literature is an } \\
\text { important factor that } \\
\text { influences the } \\
\text { success or failure of } \\
\text { channeling service } \\
\text { brand value }\end{array}$ \\
\hline $\begin{array}{c}\text { Ioanna } \\
\text { Papasolomou } \\
\text { and Demetris } \\
\text { Vrontis (2006) }\end{array}$ & $\begin{array}{c}\text { Exployee experience and views } \\
\text { about internal marketing in the } \\
\text { retail bank industry in the UK. } \\
\text { Qualitative Exploratory }\end{array}$ & $\begin{array}{c}\text { There are 4 core } \\
\text { themes in Internal } \\
\text { marketing which are } \\
\text { the basis for } \\
\text { building and } \\
\text { maintaining a }\end{array}$ \\
& & company brand. \\
\hline
\end{tabular}

Source: primary data processed (2018)

Objective: How do managers / owners and employees interpret the relationship of "internal marketing" with "brand" restaurants in North Sulawesi?

\section{Quantitative Research Methods}

\section{Sampling Method}

The population in this study were restaurant managers/owners in North Sulawesi. The sampling method is probability sampling which provides an opportunity for each member of the population to be chosen as a member of the sample.

Based on the results of data collection it was found that the number of restaurants in North Sulawesi was 92 while the number of restaurants was 727 . So the researcher decided to take the restaurant data entirely to represent the restaurant owner/manager and the number of restaurants counted by the percentage, so the number of employees who became the respondent was 103 people. So that the total number of respondents, 195 respondents. The number of questionnaires collected, 181 from 83 managers and 98 employees. 


\section{Result and discussion}

This study used PLS to analyze the data of 210 distributed questionnaires, which returned 194 questionnaires but which could only use 181 , so the response rate was $92 \%$. Testing the validity and reliability of the research instrument was carried out by a trial method. Namely, the validity and reliability tests carried out on respondents who will be taken data. In the PLS analysis, the results of testing the validity of the instrument can be seen from the AVE value while reliability can be seen in the composite reliability. The questionnaire is said to be valid if the AVE value is greater or equal to 0.50 reliable if the composite reliability value is $>0.70$. Delivery and reliability validity test results can be seen in the following table.

Table 2. Validity and Reliability Test Results of Research Instruments

\begin{tabular}{|l|c|c|}
\hline Laten Variabel & Mean Communalities (AVE) & D.G. rho (PCA) \\
\hline Komunikasi internal & 0.451 & 0.711 \\
\hline Strategi Reward & 0.712 & 0.835 \\
\hline Pelatihan & 0.646 & 0.879 \\
\hline Senior leadership & 0.896 & 0.963 \\
\hline Identifikasi branding & 0.814 & 0.968 \\
\hline Komitmen branding & 0.915 & 0.977 \\
\hline performance branding & 0.921 & 0.972 \\
\hline Loyalita branding & 0.946 & 0.989 \\
\hline
\end{tabular}

Source: primary data processed (2018)

The data in the table above explains the results of the Validity Test and Reliability of the research instruments, so that it can be seen that the instrument of this study consisting of construct variables: internal communication, reward strategy, senior leadership and identification of branding, commitment to branding, branding performance and branding loyalty are all stated valid and reliable because it meets the requirements. This can be seen from the achievement of the values obtained, namely the AVE value of more than 0.5, Composite Reliability seen in the PCA value of more than 0.7 so that it can be said to be worthy of being used as a tool for data collection.

The goodness of fit statistics is shown by a very good GoF value, 0.825 . This means that the model is good enough to be used in this study.

Fig. 1. Corr analysis result and Path coefficient concept mode

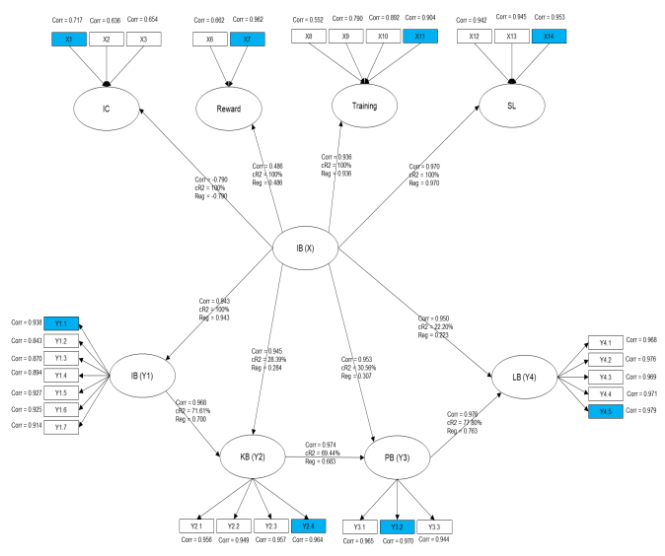

Source: data processed 2018 
The results of this study indicated that the internal brand reflected in internal communication, reward, training, and senior leadership has a significant and positive influence on brand identification, brand commitment, brand performance, and brand loyalty. In the previous study, it was mentioned that brand identification, brand commitment, brand performance, and brand loyalty are brand performance.

Furthermore, brand identification has a positive effect on brand commitment, brand commitment influences brand performance, brand performance influences brand loyalty. Among the four construct variables which are brand performance, it was found that brand identification has a high dependence on internal brand variables. These results support previous research which stated that internal brands influence the brand identity of employees who are committed and loyal to the brand. So, this study proves that internal brands influence employee behavior so that they are consistent in channel distribution.

\section{Conclusion}

Based on the results of this study, it can be concluded that the internal brand is reflected through internal communication, reward, training, and senior leadership. Through internal brands, brand performance can be improved; this can be seen in a positive and significant relationship construct variable brand identification, brand commitment, brand performance, and brand loyalty.

The results of this study are still very limited, so it needs to be also examined in other sectors outside of tourism, and analysis tools used can also be measured by other tools so that the results of this study can be more useful.

\section{Acknowledgements}

Thank you to the Ministry of Research, Technology and Higher Education of The Republic of Indonesia for funding this research.

\section{References}

[1] Sparks, B., Bowen, J., Klag, S. Restaurant and The Tourist Market, International Journal of Contemporary Hospitality Management, Vol 15, No 1 (2003).

[2] Faulkner, B. , Oppermann, M., Fredline E. "Destination Competitiveness, An Exploratory Examination Of South Australia's Core Attractions”, Journal of Vacation Marketing, Vol 5 No. 2. pp 125-139 (1999).

[3] Fontane D. Food and wine tourism in Tasmania: discussion paper for board comment tourism Tasmania Hobart (2000).

[4] Mandey Nancy H.J. , Armanu, Mintarty, Sunaryo. Effect of Internal Marketing on Restaurant Market Orientation at Manado, Indonesia Australian Journal of Basic and Applied Sciences, Vol 10, No.10, Pp 320-327 (2016).

[5] Papasolomou Ioanna Demetris Vrontis. 'Building Corporate Branding Through Internal Marketing: The Case Of The Uk Retail Bank Industry',Journal of Product \& Brand Management Vol. 15, No.1, pp. 37-47 (2006).

[6] Ahmed, P. K., Rafiq, M. Commentary: Internal Marketing Issues And Challenges . European Journal of Marketing Vol. 37 No. 9 : pp 1177 - 1186 (2003).

[7] Caruana, A. and Calleya, P.The Effect Of Internal Marketing On Organizational Commitment Among Retail Bank Managers . International Journal of Bank Marketing Vol.16 No.3 pp 108 - 116 (1998). 
[8] Foreman , S . K . and Money, A . H . Internal marketing: Concepts, measurement and application . Journal of Marketing Management 11 (8) : pp 755 - 768 (1995).

[9] Lings I. N. and G. E. Greenley. Measuring internal market orientation, Journal of service research, Vol 7 No. 3 pp. 290-305 (2005).

[10] Chang dan Chang. Effect of internal marketing on nurse job satisfaction and organizational commitment: example of medical centers in sothren Taiwan, Journal of nursing research. Vol 15 No.4 pp. 265-274 (2007).

[11] Opoku R. A., Atuobi-Yiadom N, Chong C.S.and Abratt R. The Impact of Internal marketing on the Perception of Service Quality in Retail Banking: A Ghanaian Case. Journal of Financial Service Marketing Vol 13 No. 4 pp. 317-329 (2009).

[12] Fill, C. Marketing Communications: Contexts, Strategies and Applications, 3rd ed., Prentice-Hall, Harlow (2002).

[13] Punjaisri Khanyapuss dan Alan Wilson. The Role Of Internal Branding In The Delivery Of Employee Brand Promise, ,Brand Management Vol. 15, No. 1, pp 57-70 (2007).

[14] Morgan Robert M. and Shelby D. Hunt The Commitment-Trust Theory of Relationship Journal of Marketing, Vol. 58, No. 3, pp. 20-38 (Jul., 1994). 